\title{
Biphasic Mesothelioma
}

National Cancer Institute

\section{Source}

National Cancer Institute. Biphasic Mesothelioma. NCI Thesaurus. Code C4282.

A malignant neoplasm arising from mesothelial cells in the pleura. It is characterized by the presence of neoplastic epithelioid cells and sarcomatoid features. 